\title{
FACTORS AFFECTING NURSING STAFF COMMITMENT AT GENERAL HOSPITALS IN DAMIETTA CITY
}

\author{
Rehab Mahmoud El Said Ahmad', Wafaa Fathi Sleem², Marwa Mohamed Abdel-Aleem ${ }^{3}$ \\ Bachelor Science Nursing, Faculty of Nursing-Mansoura University ${ }^{\mathbf{1}}$, Assistant Prof of \\ Nursing Administration, Faculty of Nursing-Mansoura University ${ }^{2}$, Lecture of Nursing \\ Administration, Faculty of Nursing-Port-Said University.
}

\begin{abstract}
Background: Commitment represent a strong desire to maintain nursing staff of an organization, it reflects nursing staff to achieve the organization's goals and values, a desire to stay with the organization and willingness to exert much effort to organization. Aim: assess the factors affecting nursing staff commitment at general hospitals in Damietta city. Methods and methods: A descriptive design was utilized with a sample of 421 nursing staff working at all inpatient units at Damietta general hospitals. Tools of data collection: The study tool consists of three parts ; part (I) :personal characteristics included personal and job characteristics, part (II) :Three-component organizational commitment questionnaire to measure types of nurses' commitment and the degree of nurses' commitment to their work, part (III) :factors affecting nurse's commitment questionnaire to assess the factors affecting nurses' commitment at workplace. Results: More than two thirds $70.5 \%$ of nursing staff had moderate total commitment. Conclusion: Revealed that the highest percentage among factor affecting commitment was feeling their place of work is equitable and the lowest one was for voice concern. Therefore, the study Recommendations: Orientation program for new nurses to know the goals, policies, objectives and regulation of the organization and evaluate the training needs of nursing staff periodically to develop their skill and information, regular meeting between hospital administrations, nursing administrator and nursing staff to express their concerns, and opinions and discuss their work problem and solve it.
\end{abstract}

Key wards: Commitment, Factor Affecting Commitment, Nursing Staff. 


\section{INTRODUCTION}

Organizational commitment (OC) is an important area of study to many researchers because the organizational outcome of this behavior or value, it may help to determine many work related to the employee's desire to continue working with particular organization (Govindasamy \& Jayasingam, 2008). Also, OC is "the degree to which an individual adapts with organizational values, goals and identifies with them in fulfilling their job responsibilities (Tanriverdi, 2008).

Commitment based organizations believe that OC contributes to enhance workforce and better patient services, OC as a psychological concept has been identified as an important factor, which plays a significant role in the relationship between nurse's staff and organization (Benligiray \& Sonmez, 2012). The organizational success depends on commitment of its nursing staff. It is an important factor in nurses`retention, motivation and job satisfaction. Moreover, the high committed staff may contribute to low rate of turnover and absenteeism (Krishna, 2008; Yahayae, Salles, Balassiano, Ellenbacker \& Cushman, 2012). Also, OC involves the loyalty of employee's to the organization, their readiness to put exertion on organization's behalf, the level of coincidence of personal goals with organization, and an aspiration to continue employment with the organization (Khaliq, Naeem \& Khalid, 2016).

Lamba and Choudhary (2013) mentioned that OC is a sort of strong magnetic force which binds nurse's staff with their willingness to remain attached to its organization. Additionally 'OC is a situation where an employee in line with a particular organization as well as the goals and wishes to maintain membership in organization (Robbins \& Judge, 2007). Nurses' staff commitment is important for health care institutions, not only for the quality of care, but also for patient's satisfaction (Mateja \& Brigita, 2014). As well, Organizational commitment contributes to enhance workforce and better patient services, OC as a psychological concept has been identified as an important factor, which plays a significant role in the relationship between nurse's staff and organization (Benligiray \& Sonmez, 2012 ) .

According to Allen and Meyer (1990) organizational commitment has three types namely: affective, continuance and normative organizational commitment. Affective commitment refers to affective psychological attachment to be identified with the 
organizations and engaging in the organization's activities with positive emotions; continuance commitment: refers to remaining in organization due to financial or other costs associated with leaving the organization; normative commitment: refers to the obligation to stay with organization (Ahadi \& Suandi, 2014).

Brewer (1995) identified factors that affecting nursing staff commitment as the following: Nurse identification, Trust management, Show a willingness to invest effort, Participation in decision making, Voice concern, Feel their place of work is equitable, Managerial strategies and compliance. Moreover, Lambert (2004) added that there were many factors influencing organizational commitment such as the factors interfering with job satisfaction, work experience, and large size of the organization.

\section{Significance of the study:}

One of the major effective factors in human resources in hospitals is commitment, Commitment based organizations believe that nursing staff and organizational commitment contributes to workforce stability and better patient service; hence increase hospital performance, that $\mathrm{OC}$ is characterized by the strong desire to continue the membership of an organization. Also, Commitment as a kind of psychological commitment that makes an individual internalize the goals and values of the organization and try hard to be a part of it. The degree of commitment often determines the decision to stay with the organization (Manivannan \& Kathiravan, 2016).

\section{AIM OF STUDY:}

The study aims to assess factors affecting nursing staff commitment at general hospitals in Damietta city.

\section{Research Questions:}

1. What is level of organizational commitment among nursing staff at general hospitals in Damietta city?

2. What are factors affecting nursing staff commitment at general hospitals in Damietta city? 


\section{SUBJECTS AND METHOD:}

Research design: a descriptive research design was used to achieve study aim.

Study setting: This study was carried out in all inpatient's units at two major hospitals in Damietta governorate; these are Damietta general hospital and Damietta specialist hospital, which are affiliated to Ministry Of Health at Damietta City.

Subjects :The subjects of this study included all nursing staff working at all inpatient's unit at Damietta general hospitals with a total number of 421 nursing staff, where 200 nursing staff working in Damietta general hospital and 221 nursing staff working in Damietta specialist hospital.

\section{Tool for data collection:}

One tool used to collect data and consists of three parts:

Part 1: This part included personal and job characteristics such as age, educational qualifications, and years of nursing experience.

Part 2: Three component of organizational commitment questionnaire sheet: it was developed by Meyer and Allen (1900) and adopted from Hasanin (2009) to measure types of nurses' commitment and the degree of nurses` commitment to their work. It includes 22 items concerned with three type's commitment dimensions.

\section{Scoring system:}

The item was measured against a 5-piont Likert scale from "totally accurate"5 to 1 totally inaccurate. "totally accurate" $=5$ and "accurate $"=4$ score were combined together as committed which were positive responses to committed, on other hand "totally inaccurate " =1 score and " inaccurate " =2 score were combined together as not committed which negative responses to committed, while "sometime accurate" $=3$ responses reflects moderate committed. Commitment level categorized as: $\geq 75 \%=$ highly committed, 50-75 = moderated committed, $\leq 50=$ low commitment (Kelly, 2007).

Part 3: Factors affecting nurse's commitment questionnaire sheet: it was developed by Brewer (1995) and adopted from Hasanin (2009) to assess the factors affecting nurses` commitment at workplace. It consists of 59 items grouped under 9 factors.

\section{Scoring System:}


Responses were measured on 5-point Likert scale ranging from (strongly agree)"5"score, (agree)"4"score, (sometimes agree)"3" score, (disagree)"2"score, (strongly disagree)"1" score. Strongly agree and agree were combined together to reflect positive responses to committed, Also, (strongly disagree)"1" and (disagree)"2"scores were combined together to reflect negative responses to affecting committed. While (sometime agree)"3"score represent moderate response to factor affecting committed. Factor affecting commitment level categorized as: $\geq 75 \%=$ highly factor affecting committed, 50-75 = moderated factor affecting committed, $\leq 50=$ low factor affecting commitment (Kelly, 2007).

\section{Content Validity:}

The expert's opinions validated the questionnaire sheets were tested for understanding, applicability, comprehensiveness, clarity, relevance, and ease for implementation through five experts in the field of nursing administration from the faculty of nursing in Port Said, faculty of nursing Ain Shams University and faculty of nursing Zigzag University, Changes were done according to the experts opinions. A pilot study was carried out on 43 nursing staff who were represent $10 \%$ of the total sample to test the applicability of tool before starting data collection and estimated the time needed to complete questionnaire and to assure stability of the answers.

Reliability of the tools was checked by testing for its internal consistency using a Cronbach's Alpha reliability test.

Reliability analysis for the questionnaire:

\begin{tabular}{|c|c|c|}
\hline $\begin{array}{c}\text { Part of } \\
\text { questionnaire sheet }\end{array}$ & Items & Cronbach's Alph \\
\hline (II) & $\begin{array}{ccc}\text { Dimensions of } & \text { organizational commitment } \\
\text { questionnaire sheet }(22 \mathrm{item}) & & \\
\end{array}$ & 0.887 \\
\hline (III) & $\begin{array}{l}\text { Factors affecting nurse' commitment questionnaire } \\
\text { sheet (59 item) }\end{array}$ & 0.862 \\
\hline
\end{tabular}

Ethical Consideration:

- Official permissions through formal agreement were taken from hospital medical and nursing directors to carry out the study.

- The aim of the study was explained to nursing staff that included in the study and their permission to participate was taken.

- Nursing staff included in the study were assured about confidentiality of the information gathered and it was used only for the purpose of the study. 


\section{Field work:}

The data were collected from all nursing staff working at all inpatient's units at Damietta general hospitals, the researchers was explain the purpose of the study and how to complete the questionnaire to ensure objectivity of the responses and to check that all items were answered, The actual fieldwork started at the beginning of January 2016 and was completed by the end of April 2016. Data collection through meeting with the staff nurses and they were reassured that the information collected was being treated confidentially, and it would be used only for the research purpose. Sheet were distributed, and applied by nursing staff. The time needed by nursing staff to complete the sheet was 15-20 minutes. The three shifts were studied: morning shift, afternoon shift and night shifts to complete data collection and sometimes nurses can't complete the application questionnaire, because load of duties to nursing staff. So, I come back again to complete questionnaire in another time.

\section{Statistical analysis:}

Data entry and statistical analysis were done using SPSS 21 statistical software package. Then tabulated used number and percentage, mean and standard deviation. Also, chi-Square test was used to test the difference quantitative variables. The correlation coefficient (r) test was used to assess the correlation between organizational commitment types and factors affecting nursing staff commitment. Whenever using suitable tables. Statistical significance was considered significant at p-value $<0.05 \%$.

\section{RESULTS:}

Table (1): shows personnel characteristics of studied nursing staff. The table reveals that more than half of nurses $(55.1 \%)$ had aged between 20 to 30 years old, the highest percentage of them were married (98.3\%), less than three quarters had nursing diploma (71.3\%), and half of them working in Damietta specialized hospital $(52.5 \%)$.Regarding to years of nursing experience two fifths of nurses had one to ten $(41.6 \%)$ and ten to 20 years $(41.3 \%)$ years of experience.

Table (2): showed that mean score of three types organizational commitment among the studied nursing staff. According to the table, affective commitment had the highest mean score of types of organizational commitment (64.2 \pm 14.6$)$, followed by continuance commitment $(61.8 \pm 12.9)$ then normative commitment had the last one mean score of types of organizational commitment $(61.2 \pm 15.2)$. 
Table (3): indicates that level of agreement three type's organizational commitment among the studied nursing staff. The highest number of studied sample reported their moderate level $(76.0 \%)$ of continuance commitment.

Table (4): mean scores of Factors affecting nurse's commitment among the studied nursing staff, from the table it was observed that: - the highest mean score $(72.6 \pm 11.7)$ was for feel their place of work is equitable factor among studied nursing staff. While the lowest one $(57.8 \pm 13.9)$ for the voice concern factors among the studied nursing staff.

As shown in table (5): level of agreement factors affecting nurse's commitment among the studied nursing staff, the table revealed that majority $(89.5 \%)$ of studied nursing staff reported their moderate level of factors affecting commitment.

Table (1): Personnel characteristics of studied nursing staff $(n=421)$

\begin{tabular}{|c|c|c|}
\hline \multirow[t]{2}{*}{ Variables } & \multicolumn{2}{|c|}{$\begin{array}{l}\text { Studied nursing staff } \\
(\mathrm{n}=\mathbf{4 2 1})\end{array}$} \\
\hline & No. & $\%$ \\
\hline \multicolumn{3}{|l|}{ Age (years) } \\
\hline $20-$ & 232 & 55.1 \\
\hline $30-$ & 147 & 34.9 \\
\hline $40-$ & 40 & 9.5 \\
\hline $50-<60$ & 2 & 0.5 \\
\hline Min-Max & \multicolumn{2}{|c|}{$20.0-55.0$} \\
\hline Mean \pm SD & \multicolumn{2}{|c|}{$29.9 \pm 6.7$} \\
\hline \multicolumn{3}{|l|}{ Marital status } \\
\hline Single & 3 & 0.7 \\
\hline Married & 414 & 98.3 \\
\hline Divorced & 2 & 0.5 \\
\hline Widow & 2 & 0.5 \\
\hline \multicolumn{3}{|l|}{ Educational level } \\
\hline Nursing diploma & 300 & 71.3 \\
\hline Technical institute & 75 & 17.8 \\
\hline Baccalaureate degree & 46 & 10.9 \\
\hline \multicolumn{3}{|l|}{ Place of employment } \\
\hline Damietta General Hospital & 200 & 47.5 \\
\hline Damietta Specialized Hospital & 221 & 52.5 \\
\hline \multicolumn{3}{|c|}{ Duration of nursing experience (years) } \\
\hline $1-$ & 175 & 41.6 \\
\hline $10-$ & 174 & 41.3 \\
\hline $20-$ & 71 & 16.9 \\
\hline $30-<40$ & 1 & 0.2 \\
\hline Min-Max & \multicolumn{2}{|c|}{$1.0-32.0$} \\
\hline Mean \pm SD & \multicolumn{2}{|c|}{$11.4 \pm 7.4$} \\
\hline \multicolumn{3}{|l|}{ Job position } \\
\hline Staff nurse & 373 & 88.6 \\
\hline Head nurse & 48 & 11.4 \\
\hline
\end{tabular}


Table (2): Mean scores of three component organizational commitment among the studied nursing staff $(n=421)$.

\begin{tabular}{|l|c|}
\hline \multicolumn{1}{|c|}{$\begin{array}{c}\text { Types of organizational } \\
\text { commitment }\end{array}$} & Mean(SD) \\
\hline Affective commitment & $64.2 \pm 14.6$ \\
\hline Continuance commitment & $61.8 \pm 12.9$ \\
\hline Normative commitment & $61.2 \pm 15.2$ \\
\hline Total commitment & $\mathbf{6 2 . 5} \pm \mathbf{1 2 . 4}$ \\
\hline
\end{tabular}

Table (3): Level of agreement three types of organizational commitment among the studied nursing staff $(n=421)$.

\begin{tabular}{|c|c|c|c|c|c|c|}
\hline \multirow{3}{*}{$\begin{array}{c}\text { Types of organizational } \\
\text { commitment }\end{array}$} & \multicolumn{6}{|c|}{ Commitment levels } \\
\hline & \multicolumn{2}{|c|}{$\begin{array}{c}\text { Low } \\
(\leq \mathbf{5 0 \%})\end{array}$} & \multicolumn{2}{|c|}{$\begin{array}{c}\text { Moderate } \\
(50 \%-\leq 75 \%)\end{array}$} & \multicolumn{2}{|c|}{$\begin{array}{c}\text { High } \\
(75 \% \leq)\end{array}$} \\
\hline & No. & $\%$ & No. & $\%$ & No. & $\%$ \\
\hline Affective commitment & 61 & 14.5 & 223 & 53.0 & 137 & 32.5 \\
\hline Continuance commitment & 70 & 16.6 & 320 & 76.0 & 31 & 7.4 \\
\hline Normative commitment & 90 & 21.4 & 271 & 64.4 & 60 & 14.3 \\
\hline Total commitment & 63 & 15.0 & 297 & 70.5 & 61 & 14.5 \\
\hline
\end{tabular}

Table (4): Mean scores of factors affecting nurse's commitment among the studied nursing staff $(\mathrm{n}=421)$.

\begin{tabular}{|l|c|}
\hline \multicolumn{1}{|c|}{ Factors } & Mean(SD) \\
\hline Identification & $67.5 \pm 12.2$ \\
\hline Trust management & $58.6 \pm 28$. \\
\hline Show a willingness to invest effort & $66.7 \pm 9.9$ \\
\hline Participation in decision making & $72.4 \pm 10.5$ \\
\hline Feeling positive about work & $65.3 \pm 6.9$ \\
\hline Voice concern & $57.8 \pm 13.9$ \\
\hline Feel their place of work is equitable & $72.6 \pm 11.7$ \\
\hline Managerial strategy & $67.4 \pm 11.9$ \\
\hline Compliance Total & $69.1 \pm 9.8$ \\
\hline \multicolumn{2}{c|}{} \\
\hline
\end{tabular}


Table (5): Level of agreement factors affecting nurse's commitment among the studied nursing staff $(n=421)$.

\begin{tabular}{|l|c|c|c|c|c|c|}
\hline \multirow{2}{*}{ Factors } & \multicolumn{5}{c|}{ Level } \\
\cline { 2 - 7 } & \multicolumn{2}{|c|}{$\begin{array}{c}\text { Mow } \\
(<\mathbf{5 0 \%})\end{array}$} & \multicolumn{2}{c|}{$\begin{array}{c}\text { Moderate } \\
(\mathbf{5 0 \%}-<\mathbf{7 5 \%})\end{array}$} & \multicolumn{2}{c|}{$\begin{array}{c}\text { High } \\
(\mathbf{7 5 \%} \leq)\end{array}$} \\
\cline { 2 - 7 } & No. & $\mathbf{\%}$ & No. & \% & No. & \% \\
\hline Identification & 27 & 6.4 & 268 & 63.7 & 126 & 29.9 \\
\hline Trust management & 139 & 33.0 & 231 & 54.9 & 51 & 12.1 \\
\hline $\begin{array}{l}\text { Show a willingness to invest } \\
\text { effort }\end{array}$ & 24 & 5.7 & 322 & 76.5 & 75 & 17.8 \\
\hline Participation in decision making & 10 & 2.4 & 264 & 62.7 & 147 & 34.9 \\
\hline Feeling positive about work & 8 & 1.9 & 372 & 88.4 & 41 & 9.7 \\
\hline Voice concern & 204 & 48.5 & 46 & 10.9 & 171 & 40.6 \\
\hline Feel their place of work is & 18 & 4.3 & 181 & 43.0 & 222 & 52.7 \\
\hline equitable & & & & & & \\
\hline Managerial strategy & 29 & 6.9 & 288 & 68.4 & 104 & 24.7 \\
\hline Compliance & 11 & 2.6 & 261 & 62.0 & 149 & 35.4 \\
\hline & $\mathbf{1 1}$ & $\mathbf{2 . 6}$ & $\mathbf{3 7 7}$ & $\mathbf{8 9 . 5}$ & $\mathbf{3 3}$ & $\mathbf{7 . 8}$ \\
\hline
\end{tabular}

\section{DISCUSSION:}

One of the greatest underlying factors in the success or failure of any organization is the power of its team work, and how well that power is mobilized and focused towards meeting the organization's goals and objectives (Niyonzima, 2012).Organizational commitment is an important factor, which plays a significant role in the relationship between individual and organization (Benligiray \& Sonmez, 2012). Moreover, maintaining nurse's commitment considered one of the challenges facing modern organization (Coetze, 2005). Commitment to a given profession was reflected in employee`s attitudes to their work and their behavior. Nurses demonstrating high level of commitment usually stay in their chosen field of employment for a long time (Gould \&Fontenla, 2006).

Regarding three types of organizational commitment; the present study findings showed that; slightly more than half of nursing staff had moderate affective commitment; more than two thirds of nursing staff reported that their work in the hospital has a major 
impact for them and they enjoy when they talk about it with others. This may indicate that nurse's identification stick to their hospital, and get proud with the hospital's values, goals. Their identification is evident when their work is clearly delineated, varied, innovative, and autonomous.

These findings disagree with Nasr (2017) who study the relation between shared governance, and organizational commitment among nursing managers in Port-Said hospitals, and revealed that more than one half of nursing managers have high level of affective commitment to their hospitals. As well, Graf and Zimmermann (2015) studied affective organizational commitment: where a cross-sectional studies on nurses working in 163 nursing homes in Switzerland; reclaimed that almost half of the subjects had a high level of affective commitment.

Regarding the continuance commitment, the present study findings showed that: about three quarters of nursing staff had moderate continuance commitment. This finding is related to more than two thirds of them reported that their work in the hospital is essential as it is their desire and there will be a great confusion in their life if they leave the hospital. This may be due to nurses feel that they are part of the hospitals, as much as having no alternative regarding their sustenance.

On the contrary, Elsherbiny (2013) studied the effect of leadership style of nurses manages on staff nurses absenteeism and commitment working at port-Said General Hospital and El-Zhour General Hospital and reported that the majority of the studied nurses had low level of continuance commitment toward their hospitals. Also, Nasr (2017) found via his study that majority nursing managers didn't have continuance commitment to their hospitals.

In relation to normative commitment, the study finding showed that less than two thirds of nursing staff had moderate normative commitment. More than half of them reported that they don't feel it is right to leave work at the hospital now and due to their commitment towards the hospital staff and it is a mistake to leave them now. This may be related to nurses had high feeling of ethical responsibility in a positive way and a feeling of belonging, and loyalty toward the hospital.

The finding of the present study is concordance with Abebe and Markos (2016) whose study the relationship between job satisfaction and organizational commitment through determining level of job satisfaction and organizational commitment among 
academic staff at Arab Minch University. They distributed a questionnaire on 100 academic staff. The findings revealed the higher rate for affective commitment, normative commitment and continuance commitment respectively.

Generally, the highest commitment levels of three components organizational commitment among the studied nurses was continuance commitment, followed by normative commitment, then affective commitment. These finding agree with Motazedi, Hassankhani and Ebrahimi (2012) who studied organizational commitment of nurses in Iran on nurses working in 11 hospitals of East Azerbaijan province and proved that the studied nurses had continuance commitment with a score more than affective and normative commitment. Also, Chang, Shyu, Wong, Friesner, Lanchu and Teng (2015) who investigated aspects of professional commitment in the nursing profession in northern Taiwan, and on a sample of 579 nurses and found that continuance commitment had great influence on nurses retaining.

Jena (2015) contracted the result of study founding affective commitment has the highest percentage followed by normative commitment and continuance commitment. Also, Vietnam and Nguyen (2014) contradicted the finding by studying the factors affecting employees' organizational commitment in banks in Ho Chi Minh City and found that affective commitment is the most important following normative commitment then continuance commitment.

Regarding factors affecting commitment, the finding of the present study reflects that less than two thirds of nursing staff had identification with their organization. This finding is related to the nurses' conviction that the image and reputation of the hospital are important items for them, and it is important for them knowing the hospital systems. This result may referred to the hospital's policies including: rules, hospital objectives and vision, besides goals; intervene creating a trustful environment between management and nurses.

The study reported by Kaohsiung and chen (2015) who conducted a study on the relationship between organizational trust and organizational identification on a sample of 400 registered nurses in teaching hospital in Taiwan found that the organizational justice significantly and positively affects nurses organizational identification which includes (attractive identification and correlative identification) where organizational identification significantly and positively affects organizational commitment. Added to, Buchwald (2006) Creating identification for the nurse's increases member commitment, thence 
higher identification among team members results in greater feelings of credibility toward the team.

Regarding Trust management, the finding of the present study showed that more than half of the studied nursing staff trust hospitals management, this finding is related to head nurses, where they take nurses' point of view before making a decision, even before losing their work in the hospital hurriedly. This result may be explained by that nurses confide in their superiors and deal with them in a sympathetic way, trust their managers that support them and when possible satiety their needs and help them solving their problems which make nurse's staff feel secure in their work.

Accordingly, Speritzer and Quinn (2001) spoke about the impact of trust between the managers with subordinates, they concluded that; when manager do not trust their subordinates, they are less empowering. Liou (1995) show that trust in the leader and organization was predictive of commitment to organization. Trust between a leader and subordinates, leads to a more willing subordinate and will has a more impetus to engage in extra role behavior.

Regarding to, showing a willingness to invest effort; the finding of the study showed that slightly more than three-quarters of studied nursing staff showed willingness to invest effort on their hospitals. The finding is related to nursing staff thoughts that training and personal development is important for them and makes an effect for the hospital as they make an effect for them. This result may explain the continuous training which is very important for nursing staff. Nurses who invest extra effort into their work and their hospital are trying to prove themselves and mostly like their job, their expectation of what they will be like if they are more productive, and the appreciation of others of their work would enhance their commitment to their hospital.

Moreover, Ferrer (2005) who found that investing extra effort on behalf of the organization is consistent with similarities between employee engagement and organizational commitment. Chew and Chan (2007) mention the importance of training and development that is a common form of human capital investment for individual and organizational improvements. Also, Slovenia, Lorber and Skela (2014) reported one important factor affecting commitment which is believed in successful development for commitment to job. 
Regarding to participation in decision making, the present study finding revealed that two thirds of studied nursing staff participated in decision making. This finding is resorted to that; nursing administration at the hospital should had their opinions in their work performance and feel that nurses at hospital had points of view in their own work. This result may be attributed to nursing staff participation in decision making. This leads them to be more committed at their hospital, establish and enhance nursing performance, self-confident in thinking process and able to share in problems solving process at their work place. Accordingly a feeling of security, satisfaction with their work is promoted.

In the same line, Niyonzima (2012) found that there is a positive relationship between employee's involvement, decision-making process and organizational citizenship behavior in insurance companies located in Kigali city Rwanda. Its worthy to say that Aiken, Clarke, Sloane, Sochalstisis and Silbar (2002) found effective decision making after sharing ideas, and information, increase productivity.

Regarding nurses positive feeling about their work, the present study revealed that there more than four-fifths of studied nursing staff feel positively regarding work in the hospital. The finding is related to nursing career nature, added that: they think nurses at the hospital must feel that they are chief part of hospital entity. This may be attributed to nurses had friendly relationship in hospital and work being a team. This may be due to that they are more familiar with their work, had updated knowledge, and skills, accordingly high self-confidence and self-actualization.

This was supported by Boehm and Lyubomirsky (2008) marked that happy employee enjoy more success in the work place than the less happy, and also stated that happy employee have a higher degree of autonomy in their jobs. Furthermore, Eisenberger (2003) reported a positive relationship existing between employee's perception of an organization fulfilling its obligation to them and the employee's consequent expressed commitment to the same organization.

Regarding to Voice concern, the finding of the present study showed less than one fifths of the studied nursing staff with of voice concern inside the hospital. This finding is related to; nursing staff had ways to introduce a formal submission file complaints and grievances. This result may be explained by; nursing staff is convinced that they should not express their undesired changes at work or unwanted work situation, for example: 
problems faced in night shift, workload, or occupational stress. Moreover, Koys (1991) stated that grievance resolution mechanisms, increase nurse's commitment, Andrew and Ian (2001) found that employees who believe speaking up and/or waiting patiently for a problem to get resolved are likely to be more committed.

Regarding to equitable of work place, the finding of the present study showed that more than two-fifths of nursing staff feel that their work place is equitable. This finding is resorted to, nurses think that self confidence in their character is important to work, and they do some personal sacrifices to stay working at the hospital. This might be attributed to the fact that studied nurses perceived that salary and rewarding as intrinsic and extrinsic incentives were equal and fair, besides; perceived bonus and wages are equal to their effort at the hospital.

Accordingly, Ayeni (2007) showed that money as the most important factor in motivating workers to achieve greater productivity and also incentives wage systems as a means of stimulating workers to higher performance, commitment, and eventually satisfaction. Also, DeGieter (2006) found that the rewarding potential of different aspects of the nursing profession in detail, in order to identify nurses rewards, which will be used in future studies concerning nurse's performance, commitment and/or intentions to leave the hospital.

Regarding to Managerial strategies, findings of present study revealed more than two-thirds of nursing staff are satisfied with managerial strategy in their hospitals. The findings of the study showed that nurses had effect on the direction of work, and nursing staff understand their work and its relation to the objectives of the unit. This may be attributed to the nursing staff acceptance of managerial strategy in their workplace as plans, policies and processes, and their weariness that there is delegation of authority from superiors to subordinates.

Kanter (1993) stated that organizational structures are the key to determining how employees behave in the work setting, and nurses who are empowered by the structural characteristics of the organization are more likely to satisfy with their jobs, more committed and feel that they have control over their work or autonomy. Added to, Pillia, Schriesheim and Williams (1999) found transformational leadership style and transactional leadership style to be positively related to organizational outcomes such as 
performance, job satisfaction and organizational outcomes such as performance and organizational commitment.

Regarding to nurses compliance factor, the result of the study indicated that there was two-thirds of nursing staff reported that they are satisfied with official formal compliance in hospital. This finding was related to nurses conviction that the extended relationship with hospital is necessary and the nursing administration respond in an appropriate manner with the concerns of nurses. This may related to type of supervision and guidance, governing policies, as well as some unreasonable beliefs related to the efficacy of the negative compliance behaviors, suffering from rigid schedules, or no fixed shift (especially night shifts), low incentives, and defects of supplies and equipment at work.

Generally, results of the current study showed that the highest percentage was for feel their place of work is equitable. While, the lowest percentage was voice concern among total factors affecting nursing staff commitment. Malaysia and Salim (2014) in concordance with the aforementioned finding and revealed that most of participants were satisfied with the nature of work and least satisfied with operating condition and promotion, indicating the importance of procedural justice and the level of fairness on the level and organizational commitment.

\section{CONCLUSION:}

\section{Based on study findings, it can be concluded that:}

More than two thirds of nursing staff had moderate total commitment. Also, about slightly more than half had affective commitment; three quarters had moderate continuance commitment, and less than two thirds had normative commitment. Also, the highest percentage among factor affecting nursing staff commitment was for feel their place of work is equitable and the lowest one was voice concern.

\section{RECOMMENDATIONS:}

Based on the results of the present study, the following recommendations were suggested:

- An orientation program should be planned for new nurses about the goals, policies, objectives and regulations of the organization. 
- Regular meeting between hospital administration, nursing administrator and nursing staff to express their concerns, and opinions and discuss their work problem and solve it.

- Nursing staff should be participated in the decision-making as well as the inside department to achieve appropriate method to solve problem and conflict facing them.

- Evaluate the training needs of nursing staff periodically to develop their skill and information.

- Hospital administration should motivate and encourage the nursing staff through give a certificate of appreciation for the work, effective communication to increase commitment and loyalty to the hospital which increases the investment efforts towards their hospital.

- Nursing administrator must be discuss the factors that affect the nursing staff commitment to the hospital and discuss these factors with hospital administrator and know what the problems inside the hospital that affecting nursing staff commitment and how to overcome it.

\section{REFERENCES:}

Abebe, T. and Markos, S. (2016). The Relationship Between Job Satisfaction And Organizational Commitment In Public Higher Education Institution: The case of Arab Minch University, Ethiopia. International Journal of Research in Business Management, (4):24-27.

Ahadi, S. and Suandi T. (2014). Structural empowerment and organizational commitment: The mediating Role of psychological empowerment in Malaysian Research Universities. 3(1): 44-65.

Aiken, L.H., Clarke, S.P., Sloane, D.M., and Silbar, J.H. (2002). Hospital nurse staffing and patient nursing. Journal of American medical association,16(1):288.

Allen, N. and Meyer, J. (1990): The measurement and antecedents of affective, continuance and normative commitment to the organization journal of occupational psychology (63)1:1-18.

Available at :www.google.com. 
Bateman, T. and Brewer, A.(1995). Managerial strategy and nurse commitment in Australian hospital. journal of advance nursing. 21(1):789-799.

Chang, Y.H., Shyu, L.Y., Wong, K.M., Friesner, D., Chu, L.T and Teng, I.H. (2015). Which Aspects of Professional Commitment Can effectively Retain Nurses in the Nursing Profession? Journal Of Nursing Scholarship19(1):468-476.

Coetzee, M. (2005): Employee commitment. University of Pretoria,12(1)55-60.

Cohen, A. (2007). Commitment before and after: An evaluation \& reconceptualization of organizational commitment. Human Resource Management Review, 17(2):336-354.

El-Diasty, M.A. (2010). Relationship between occupational stress and organizational commitment among nurses in hospitals in Port Said city. Unpublished Master Thesis. Suez Canal University, Faculty of nursing: 88-90.

Elsherbiny, A.M. (2013). The effect of leadership style of nurse managers on staff nurses absenteeism and commitment in selected hospitals in Port Said city. Unpublished Master Thesis. Port Said University. Faculty of Nursing: 43-47.

Goetsch, D.L. and Davis, S.B. (2006).Quality Management Introduction to Total Quality Management For Production, Processing. and Services. Jersey: person education.17 (1):118.

Gould, D. and Fontenla, M. (2006). Commitment to nursing: Results of a qualitative interview study. Journal of nursing management 14(2):213-221.

Hasanin, S.G. (2009). Study of factors affecting nurses commitment at work , unpublished thesis Alexandria university:80-93.

Jena, R.K. (2015). An assessment of demographic factors Affecting organizational commitment among shift workers in India, institute of management technology, 20(1):5962.

Kafashpour, A., Mortazavi, S., Pour, S. (2012).Impact of psychological contracts on organizational trust and commitment of nurses in Ghaem hospital - Mashhad province. Iran Hospital, 11(4):65-74. 
Lamba, S. and Choudhary, N. (2013). Impact of HRM practices on organizational commitment of employees. International journal of advancements in Research and Technology April-2013. 4(2): 407-423.

Manivannan, M. and Kathiravan, C. (2016). Organizational commitment among the bank employees in Cuddalore Distorict. International journal of Research in Economics and Business Management. 5(5):55-59. http://www.wrpjournals.com/V/IJREBM.

Nguyen, T.N. Mai, K.N. and Nguyen P.V. (2014). Factors affecting employees ' organizational commitment . A study of Banking staff in HO chi Minh city, Vietnam. Journal of advanced management science, 2(1):7-11.

Niyonzima, T. and Rwanda, K. (2012). Workers' Involvement, Decision Making And Organizational, Citizenship Behavior: Evidence From Insurance Companies in Kigali city, Rwanda55-60.

Robbins, S.P., Timothy, A., Jude, A. and Sanghi, S. (2008). Organizational Behavior, Pearson, Printice Hall, Delhi,91.

Salim, M., Kamarudin, H. and Abdul Kadir, B.M. (2014). Factors Affecting organizational commitment Among Lectures in Higher educational institution in Malaysia. Paper conducted to determine MARA/Professional Colleges lecturer's perception on organizational commitment.44-51.

Talebia, N.H. and Hosseini, M. (2015). Correlation Between Organizational Commitment and Organizational climate of Physical Education Teachers of Schools of Zanjan. International Journal of Sport Studies. Science Research Publications,5(2):181185. Available online at htty:www.ijssjournal.com.

Vacharakiat, M. (2008).The Relationships of Empowerment, Job Satisfaction, and Organizational Commitment among Filipino and American Registered Nurses Working in the USA. Unpublished Doctoral Thesis is University of George Mason.66-70.

Yarameshla, Z., Darvish, A.Z. and Sadaghiani, S.J. (2015). Review of Factors Affecting Organizational Commitment With The Approach of Desire for Happiness in Agricultural Bank Headquarters in Tehran,3(3):57-62.

Zhang, D. and Jing, L. (2014). Does organizational commitment help to promote university faculty's performance and effectiveness? 23(2): 202-204. 


\section{دراسة العوامل المؤثرة علي انتماء هيئة التمريض في المستثفيات العامة بمدينة دمياط}

رحاب محمود سيد أحمد ـ أ.م.د/وفاء فتحى سليم - م/ مـروة محمـد عبد الـعلـيـم

بكالوريوس تمريض _كلية التمريض _جامعة المنصورة ،استاذ مساعد ادارة التمريض__كليه التمريض__جامعة المنصوره، مدرس ادارة التمريض_ كلية التمريض__ جامعة بورسعيد.

\section{الــــلاصــة}

يمثل الانتماء علاقة مرتبطة بين هيئة التمريض و المستشفي، وهو يعكس اتجاه هيئة التمريض لتحقيق أهداف وقيم هذه

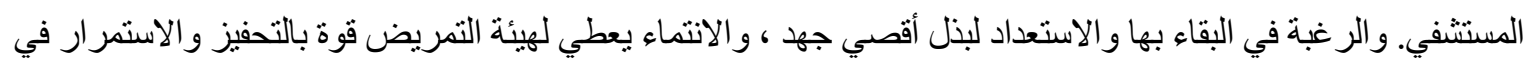

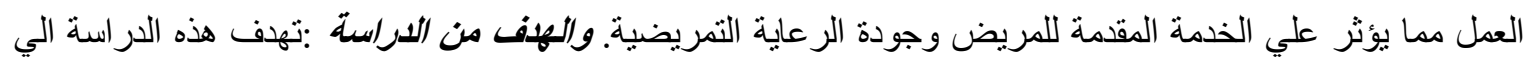
معرفة العو امل المؤثرة علي انتماء هيئة التمريض في المستشفيات العامة بمدينة دمياط. شارك في هذه الدراسة عدد أربعة مائة وواحد و عثرون من هيئة التمريض وتتثمل مستشفى دمياط العام مائتين من هيئة التمريض و مستثفى دمياط التخصصي مائتين وواحد وعشرون من هيئة التمريض. أدوات جمع البياتات : استمارة استيان واحدة تتكون من ثلاث

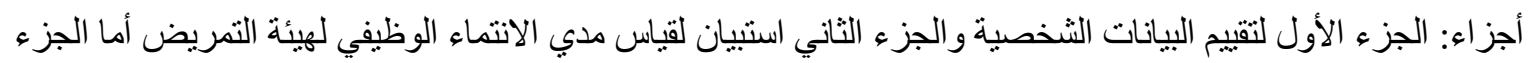
الثالث استيان لدراسة العوامل المؤثرة علي انتماء لهيئة التمريض.وقد أظهرت نتائج الدراسة انه أكثر من ثلثي هيئة التمريض 70,5\% لديهم انتماء متوسط المستوي للمستشفي اللآتي يعملن بها. والخلاصة وجد أن أعلي نسبة من العوامل

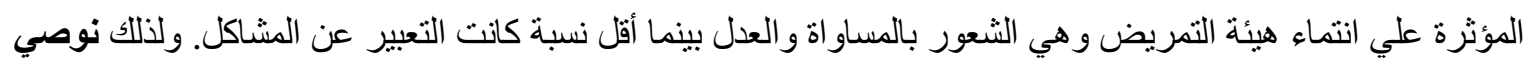
بعمل برنامج تدرييي للممرضات لمعرفتهم للمؤسسة وسياساتها وأهدافها ولوائحها، وتقييم احتياجات التدريب لهيئة

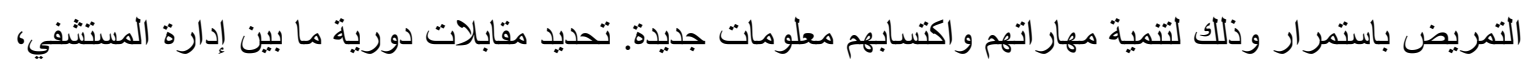

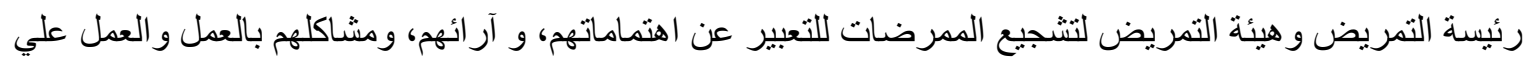

ايجاد حلول لها.

الكلمات المرشدة: الانتماء، هيئة التمريض، العوامل المؤثرة علي الانتماء. 